\title{
An Overview of the Synoptic Antarctic Shelf-Slope Interactions (SASSI) project for the International Polar Year
}

\author{
K. J. Heywood ${ }^{1}$, R. Muench ${ }^{2}$, and G. Williams ${ }^{3}$ \\ ${ }^{1}$ School of Environmental Sciences, University of East Anglia, Norwich, UK \\ ${ }^{2}$ Earth and Space Research, Seattle, USA \\ ${ }^{3}$ Antarctic Climate and Ecosystems Cooperative Research Centre, University of Tasmania, Hobart, Australia \\ Correspondence to: K. J. Heywood (k.heywood@uea.ac.uk)
}

\begin{abstract}
As Guest Editors, we introduce the special issue of Ocean Science dedicated to the Synoptic Antarctic ShelfSlope Interactions (SASSI) project for the International Polar Year. We set the scientific context for SASSI and note the objectives and goals of the project. The observational data set collected around Antarctica is summarised, and the scientific results of SASSI are briefly introduced.
\end{abstract}

\section{Introduction}

This paper provides a brief introduction to the special issue of Ocean Science dedicated to the Synoptic Antarctic Shelf Slope Interaction (SASSI) project. SASSI was initiated by the iAnZone (international Antarctic Zone) group, an affiliated programme of SCOR and SCAR, as a contribution to the International Polar Year (IPY). The IPY years were 2007-2009, but because of the unpredictability of polar logistics, coupled with funding constraints, the SASSI observations extended until 2010. Whilst it could be argued that this stretches the definition of "synoptic" beyond normal usage, it remains the case that SASSI provided the greatest temporal concentration ever of marine measurements around Antarctica. Further, it stimulated the first concerted effort to measure ocean conditions along the continental shelf and slope during the austral winter. Here we state the motivations for SASSI and summarise the significant findings, both published in this special issue and in recent publications elsewhere.

\section{The Science issues}

The Antarctic continent, with its vast ice sheets that sequester much of the world's freshwater, is separated from the deep ocean by a complex peripheral boundary typified by coastal, shelf and slope currents and fronts. Processes associated with this boundary couple the freshwater resources of the polar icecap and the deep ocean. Freshwater that passes from the continent northward through this boundary conditions the global ocean through its impact on the formation of dense water that drives shallow and deep modes of the meridional overturning circulation (MOC) (Richardson et al., 2005). These processes strongly impact global climate, both through the ocean (influencing the strength and properties of the MOC) and through the atmosphere (influencing the heat released to the southern hemisphere atmosphere). Quantitative knowledge of the moisture/freshwater budget remains one of the greatest uncertainties in climate modelling, particularly in the southern hemisphere. Prior to SASSI, the few historical sections across the marginal ocean systems that surround Antarctica showed a broad variety of geographically varying characteristics. Some revealed a westward coastal current, others a complex system of coastal, shelf break and slope currents (see for example Jacobs, 1986, 1991; Fahrbach et al., 1992, 1994; Muench and Gordon, 1995; Heywood et al., 1998, 2004; Baines and Condie, 1998; Thompson and Heywood, 2008). The currents and associated fronts, resulting from lateral gradients in temperature, salinity and density, comprise dynamic barriers that impact cross-shelf transport of water, salt and heat. These influence turbulent mixing in the ocean over the continental slope and, by so doing, impact the depths to which dense bottom waters ultimately ventilate the ocean. Locally strong tidal currents further interact 
with these currents and provide associated turbulent mixing. Through transport of heat beneath the continental ice, these flows influence the rate of ice melting. These systems effectively control the rate and geographical distribution of the meridional fluxes of volume, heat and freshwater, impacting in turn the Antarctic freshwater budget. Even existing coarse resolution coupled climate models now indicate a significant impact of Antarctic freshwater on global climate on time scales from months to centuries. The global relevance of Antarctic processes was recently highlighted in a special issue of Oceanography, describing recent results and ongoing research of the US Antarctic Research Program (Ducklow et al., 2012).

Despite considerable scientific interest and ample evidence that the resident processes play significant roles in global climate, the Antarctic margins at the end of the 20th century were neither quantitatively well documented nor dynamically well understood. Our knowledge was based on highly non-synoptic data obtained from widely different regions during different years under the auspices of projects having different, occasionally even disparate, scientific objectives. Thus the themes set forth in the 2004 CLIVAR/CliC/SCAR Southern Ocean Panel IPY Strategy document (available at http://www.clivar.org/sites/default/files/ SOIPY.pdf) included (1) Antarctica and the Southern Ocean in the global water cycle and (3) Climate processes at the Antarctic continental margin. SASSI was designed to increase scientific understanding of both these themes. The goal of SASSI was to obtain a first-ever circum-Antarctic, near-synoptic data set that would avoid the confusion associated with non-synoptic sampling of spatially and temporally varying processes. Interannual variability, such as that associated with the El Nino-Southern Oscillation, the Southern Annular Mode, or the Antarctic Circumpolar Wave, as well as secular change, leads us to anticipate significantly different ocean, ice and wind fields, forcing different coastal systems and fluxes during different years. The majority of the available data have been collected during austral summer, when withdrawal of the seasonal sea ice cover allows access for non-ice-strengthened research vessels. Although seasonal coverage has been extended through use of moorings and drifting buoys, winter programmes have been largely restricted to the Weddell Sea. Consequently, our documentation of seasonality in the shelf and slope currents and frontal systems has been limited. Finally, geographical spacing of samples has frequently been too coarse to define the dynamically important features adequately to understand their dynamics. SASSI was designed to address some of these observational deficiencies. IPY offered a unique opportunity to focus our efforts on obtaining a near-synoptic data set that resolved, for the first time, the critical processes for climate.

\section{Objectives of SASSI}

The SASSI objectives were to:

1. Obtain a synoptic circumpolar view of the oceanography of the Antarctic shelf and slope

2. Assess, as quantitatively as possible, the properties and amount of inflow of warm, saline deep water onto the continental shelf

3. Assess the role of this onshore heat transport in melting sea ice and ice shelves

4. Improve our knowledge as to where, when and how this oceanic inflow is transformed over the shelf domain into dense Shelf Water and its subsequent derivative Antarctic Bottom Water, through the net cooling and freshwater fluxes during the seasonal sea ice melting/freezing cycle

5. Assess the importance of ice shelves in the net freshening process

6. Understand the dynamics of the coastal current and slope front systems, and how they influence the exchanges between sea ice, glacial ice, coastal and deep ocean waters

7. Quantify freshwater transports around Antarctica driven by currents and through atmosphere-ocean-ice interaction

8. Assess the degree to which current coupled ocean-ice models represent the shelf system and its variability

9. Design a long-term monitoring system over the Antarctic continental margins that can act as an early indicator of global climate changes

10. Identify key Antarctic shelf/slope processes that will have to be included, either as sub-gridscale models or parameterisations, in future climate models.

\section{Review of progress}

The SASSI observational data set (Table 1 and Fig. 1) represents the efforts of many different countries and groups. These groups include many, such as the Brazilian SOSCLIMATE (Southern Ocean Studies for Understanding Global Climate Issues, www.goal.furg.br) project, that were funded as a result of the international framework that SASSI provided. Examples of successful collaborations include the ACROSS (Antarctic CRossroad Of Slope Streams, http: //southernoceans.tamu.edu/across) project in the northwest Weddell Sea, bringing together US, Argentinian and Spanish oceanographers, and the shared voyages of Australian, French and Japanese scientists working off Adélie Land. 
Table 1. Moorings and Sections contributing to the SASSI project

\begin{tabular}{|c|c|c|c|c|c|}
\hline Mooring/Section & Location & Dates & P.I. & Country & Project/Reference \\
\hline Section & $\begin{array}{l}\text { East Antarctica, } \\
115-125^{\circ} \mathrm{E} \text {. }\end{array}$ & Sep-Oct 2007 & Williams, G. & AUS & SIPEX \\
\hline 3 Moorings & $\begin{array}{l}\text { Antarctica, south of } \\
\text { Tasmania }\left(66^{\circ} \mathrm{S}\right)\end{array}$ & 2010 & Rintoul, S. & AUS & SASSI/CASO \\
\hline Section & $\begin{array}{l}\text { Australian-Antarctic Basin } \\
\left(50-66^{\circ} \mathrm{S}, 140^{\circ} \mathrm{E}\right)\end{array}$ & 2008 & Rintoul, S. & AUS/JPN & Shimada et al. (2011) \\
\hline Sections/Moorings & $\begin{array}{l}\text { Weddell Sea/Antarctic } \\
\text { Peninsula }\end{array}$ & $\begin{array}{l}\text { 2000-2006, } \\
2008-2012\end{array}$ & Mata, M. & BRA & $\begin{array}{l}\text { DOVETAIL; GOAL; } \\
\text { WWOS; SOS I, II, III; } \\
\text { POLARCANION. }\end{array}$ \\
\hline Sections & Adelie Land & $2007-2010$ & Houssais, M. N. & FRA & $\begin{array}{l}\text { Lacarra et al. (2011); } \\
\text { ALBION }\end{array}$ \\
\hline Section & $\begin{array}{l}\text { Weddell Sea \& Antarctic } \\
\text { near } 0^{\circ} \mathrm{W} \text {. }\end{array}$ & 2008 & Fahrbach, E. & GER & \\
\hline Sections & $\begin{array}{l}\text { North-western } \\
\text { Weddell Sea }\end{array}$ & $\begin{array}{l}\text { Feb-Apr 2008; } \\
\text { Jan-Mar } 2009\end{array}$ & $\begin{array}{l}\text { Fahrbach, } \quad \text { E., } \\
\text { Flexas, M. }\end{array}$ & GER/SPA & Hellmer et al. (2011) \\
\hline Moorings & Ross Sea & 2006 (pre-sassi) & Bergamasco, A. & ITA & PNRA/PolarDOVE \\
\hline 4 Moorings & Cape Darnley \& Polynya & 2008-2012 & Ohshima K. & JPN & JARE \\
\hline Sections & East Antarctica & 2009-2012 & Ohshima K. & JPN & JARE \\
\hline Moorings & Weddell Sea & 2009,2010 & Fer, I., Osterhus, S. & NOR & BIAC \\
\hline Section & Weddell Sea & 2012 & Gammelsrod, T. & NOR & \\
\hline Section/Moorings & Fimbul Ice Shelf & 2009-2012 & Nost, O. E. & NOR & FIS-TTB \\
\hline Moorings & Macquarie Ridge & Mar 2007-Apr 2008 & Williams, M. & NZL & \\
\hline Section & Prydz Bay & Jan 2007 & Antipov, N. N. & RUS & \\
\hline Section & Lazarey Sea & Feb 2007 & Antipov, N. N. & RUS & \\
\hline Section & $\begin{array}{l}70-74.5^{\circ} \mathrm{S}, 105^{\circ} \mathrm{W}, \\
\text { Pine Island Bay }\end{array}$ & Feb, 2008 & Antipov, N. N. & RUS & Antipov et al. (2009) \\
\hline Section & $\begin{array}{l}\text { North-western } \\
\text { Weddell Sea } \\
\left(60-62^{\circ} \mathrm{S}, 48-56^{\circ} \mathrm{W}\right)\end{array}$ & Jan 2008 & Palmer, M. & SPA & Palmer et al. (2012) \\
\hline Section & $\begin{array}{l}\text { South Scotia Sea, } \\
\text { Powell Basin }\end{array}$ & Jan 2008 & Gomis, D. & SPA & Palmer et al. (2012) \\
\hline 2 Moorings & South Scotia Ridge & $\begin{array}{l}\text { Deployed Feb 2009, } \\
\text { Recovered Feb } 2010 .\end{array}$ & Flexas, M. & SPA & \\
\hline Section & $\begin{array}{l}\text { Weddell Sea, Bransfield } \\
\text { Strait, Bellinghausen Sea }\end{array}$ & Feb 2009 & Flexas, M. & SPA & \\
\hline Mooring & South Scotia Ridge & 2010-2011 & Flexas, M. & SPA & \\
\hline Moorings & Amundsen Sea & 2008-2009 & Wahlin, A. & SWE & \\
\hline Moorings & $\begin{array}{l}\text { McMurdo Sound, } \\
\text { Ross Sea }\end{array}$ & 2010-2011 & Wahlin, A. & SWE & \\
\hline Section & $\begin{array}{l}72-73^{\circ} \mathrm{S}, 17-20^{\circ} \mathrm{W}, \\
\text { Weddell Sea }\end{array}$ & Jan-Feb 2009 & Heywood, K. J. & UK & Chavanne et al. (2010) \\
\hline Moorings & $\begin{array}{l}72-73^{\circ} \mathrm{S}, 17-20^{\circ} \mathrm{W} \\
\text { Weddell Sea }\end{array}$ & Feb 2009-Feb 2010 & Heywood, K. J. & UK & Graham et al. (unpublished) \\
\hline Moorings & $\begin{array}{l}\text { Western Antarctic } \\
\text { Peninsula } \\
\text { Continental Shelf }\end{array}$ & 2007-2010 & Martinson, D. G. & US & Martinson and McKee (2012) \\
\hline Moorings & Scotia Sea & Feb-Mar 2009 & Orsi, A. & US/ARG & ACROSS \\
\hline Moorings & West Antarctic Peninsula & 2007-2010 & Martinson, D. G. & US & Martinson and McKee (2012) \\
\hline
\end{tabular}

This special issue of Ocean Science brings together many early results of the SASSI project. Many more are expected to emerge over the coming decade as the mooring time series are analysed and the myriad data sets synthesised. By compiling many years of observations to the east of the Antarctic Peninsula, the most recent being SASSI sections, Hellmer et al. (2011) provide compelling evidence for a decrease in salinity over recent decades of continental shelf water masses. They relate this to a reduction in sea ice formation and higher precipitation during the late 20th century. This freshening is significant not only because water masses on the Antarctic continental shelves feed into dense overflows that contribute to Antarctic Bottom Water, but also because Antarctic shelf water properties impact the access of ocean heat to sub-ice shelf cavities where they contribute to ice melting. 


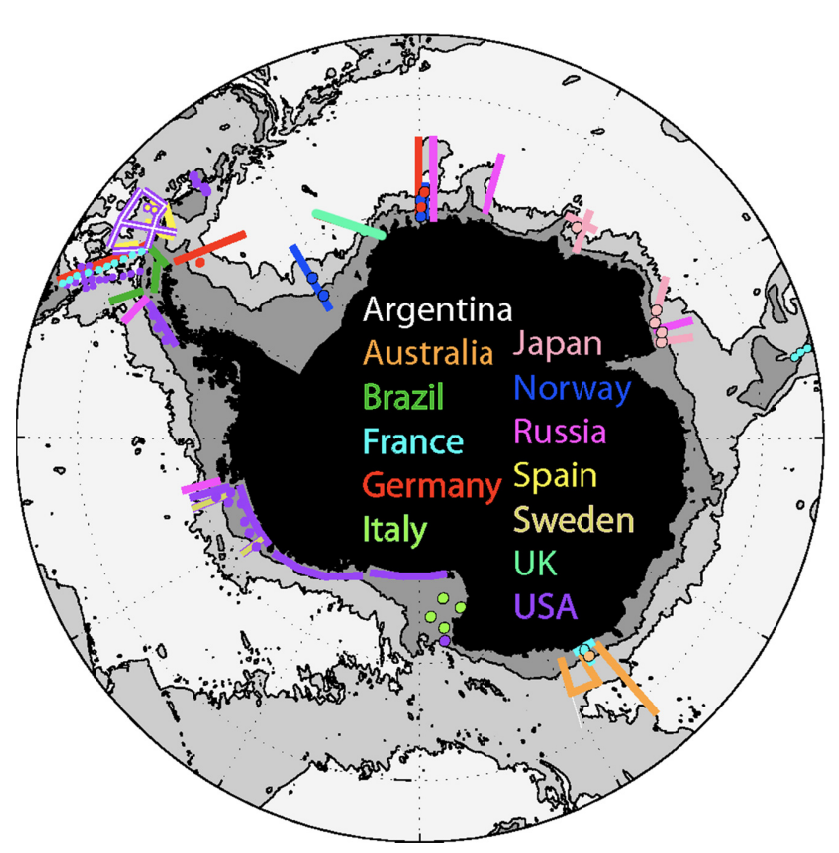

Fig. 1. A schematic summary of the activities (moorings and CTD sections) undertaken as contributions to the SASSI programme.

SASSI observations were collected not only from conventional ship-based CTD surveys or mooring deployments. Williams et al. (2011) use CTD data from tagged elephant seals to document for the first time the stratification and mixing processes due to sea ice formation in Commonwealth Bay and the Adélie depression, East Antarctica. Sea ice growth rates derived from heat and freshwater budgets constructed using these data are consistent with those derived from satellite sea ice observations. Such high temporal and spatial resolution data sets during autumn are difficult to obtain by other means in such an inaccessible region frequently covered in sea ice. This highlights the important role that tagged marine mammals are likely to play in the future Southern Ocean observing system (SOOS), designed to optimise the management of their habitat in an era of global change.

SASSI placed a strong focus on the role of the Antarctic Slope Front and its associated currents. Mathiot et al. (2011) reveal the essential ingredients necessary to accurately model this current. Models with a resolution coarser than $0.5^{\circ}$ are unable to capture the dynamics, emphasising the need to parameterise shelf-slope exchange processes in coarser climate models. The seasonal cycle and the mean transport of the Antarctic Slope Current are shown to be determined by the strength of the westward wind speed along the Antarctic coast.

Martinson and McKee (2012) deployed thermistor moorings for $\sim 3$ years (2007-2010) to understand how Upper Circumpolar Deep Water reaches the continental shelf of the western Antarctic Peninsula where the ACC impinges on the continental slope. The dominant mechanism is found to be eddies, with upwelling also playing a possible role, while flow into cross-shelf troughs and ACC meanders appear less important. Understanding these processes and their variability is key to accurately predicting the future rate of melting of the vulnerable ice shelves in the Amundsen and Bellingshausen Seas.

In addition to stimulating circumpolar observations on the Antarctic shelf and slope, SASSI encouraged the analysis of results from global models and ocean reanalyses. Kerr et al. (2012) used the eddy resolving $\left(1 / 12^{\circ}\right)$ forced ocean model OCCAM to assess processes linking the characteristics of water masses on the continental shelf with those of the outflowing dense deep and bottom waters from the Ross and Weddell seas. They showed that the model was able to simulate the observed seasonal and interannual variability of the volume transport of dense water.

Shimada et al. (2012) found long-term changes (19952008) in water masses, volume transports and stratification through repeated north-south sections across the AustralianAntarctic Basin. Warming, freshening and reduction in transport (particularly of Ross Sea Bottom Water) were found to have occurred over this time period. Documenting such changes, and testing how well climate models can reproduce the observed variations, is a primary priority for future analyses of SASSI data sets.

Other SASSI results have been presented elsewhere; we identify a selection here. Antipov et al. (2009) summarise hydrographic and biogeochemical observations collected during several cruises, including a section in Pine Island Bay. Wåhlin et al. $(2010,2012)$ use field data to demonstrate flow of Warm Deep Water onto the central Amundsen shelf and present analytical results, supported by field data, showing potential impacts of the Antarctic Circumpolar Current on this on-shelf flow. The analytical results support the strong impacts of oceanic boundary layer effects on flow across the continental slope, and emphasize the need for inclusion of these relatively small scale processes either through nested high resolution models or parameterizations. Chavanne et al. (2010) studied the dynamics of the Antarctic Slope Current and were able to confirm the presence of an eastward undercurrent using data from two hydrographic sections occupied in early 2009. They suggest that this undercurrent may be associated with coastally trapped waves propagating along the Antarctic continental slope, and that this may be an important process for exchange of water and heat across the shelf break. Williams et al. (2010), using sea-ice based oceanographic platforms to conduct rare wintertime measurements, reported a bottom-intensified intrusion of warm water on the shelf break north of the rapidly thinning Totten Glacier. Palmer et al. (2012) use a box inversion of a section circumnavigating the South Scotia Ridge at high resolution to quantify outflow of Weddell Sea waters into the Scotia Sea. Lacarra et al. (2011) describe the hydrographic regimes and water mass characteristics of the Antarctic continental 
shelf between $138^{\circ} \mathrm{E}$ and $146^{\circ} \mathrm{E}$ during $2007-2008$ SASSI campaigns. A Japanese IPY mooring project offshore from Cape Darnley recently confirmed the supply of new Antarctic Bottom Water to the Weddell-Enderby Basin (K. Ohshima and Y. Fukamachi, personal communication, 2012).

\section{Where next for SASSI science?}

Although significant efforts were expended during SASSI, we have really only started on our journey to understand oceanographic processes on the continental shelf and slope of Antarctica. Large portions of the circumpolar region are virtually undocumented and have not yet been studied. SASSI coverage was most dense in the Weddell, Ross and Bellingshausen-Amundsen sectors. The number of moored arrays in Antarctica remains minimal when compared with other portions of the global ocean. Coverage from small CTD tags mounted on marine mammals during IPY has significantly improved our knowledge of winter water properties, however, further efforts are required to properly assess even first order signals such as the seasonal cycle.

The importance of the Antarctic continental shelves has been further emphasized in recent years through the rapid seaward acceleration of the West Antarctic glaciers. The ocean's role in bringing heat to the underside of ice shelves is now well recognised, however, our understanding of the controlling processes remains incomplete. For example, the slope front may be important in either facilitating or preventing this process in different locations and at different times. It is clear that the SASSI data sets constitute an important legacy of IPY and will form the basis for future studies of climate change around Antarctica.

Acknowledgements. We would like to thank all participants in SASSI for their collaborative spirit and enthusiasm. We thank SCAR for funding some scientific management, Ben Webber for compiling Table 1, and Steve Diggs at CCHDO for his sterling efforts for data management of SASSI. We thank the International Polar Year organisers for stimulating and supporting our work.

Edited by: E. J. M. Delhez

\section{References}

Antipov, N. N., Batrak, K. V., Dukhova, L. A., Kuznetsov, V. L., and Maslennikov, V. V.: Hydrological-hydrochemical studies performed onboard R/V Akademik Fedorov during the 53rd Russian Antarctic Expedition, Oceanology, 49, 144-147, doi:10.1134/S0001437009010172, 2009.

Baines, P. G. and Condie, S.: Observations and modelling of Antarctic downslope flows: A review, in: Ocean, Ice, and Atmosphere: Interactions at the Antarctic continental margin, edited by: Jacobs, S. S. and Weiss, R. F., Antarctic Research Series, 75, Washington DC: AGU, 29-49, 1998.
Chavanne, C. P., Heywood, K. J., Nicholls, K. W., and Fer, I.: Observations of the Antarctic Slope Undercurrent in the southeastern Weddell Sea, Geophys. Res. Lett., 37, L13601, doi:10.1029/2010GL043603, 2010.

Ducklow, H. A. Orsi, and Wellner, J. S.: Introduction to the Special Issue on Antarctic Oceanography in a Changing World, Oceanography, 25, 14-17, doi:10.5670/oceanog.2012.68, 2012.

Fahrbach, E., Rohardt, G., and Krause, G.: The Antarctic coastal current in the southeastern Weddell Sea. Polar Biol., 12, 171$182,1992$.

Fahrbach, E., Rohardt, G., Schroder, M., and Strass, V.: Transport and structure of the Weddell Gyre, Ann. Geophys., 12, 840-855, 1994.

Hellmer, H. H., Huhn, O., Gomis, D., and Timmermann, R.: On the freshening of the northwestern Weddell Sea continental shelf, Ocean Sci., 7, 305-316, doi:10.5194/os-7-305-2011, 2011.

Heywood, K. J., Locarnini, R. A., Frew, R. D., Dennis, P. F., and King, B. A.: Transport and water masses of the Antarctic Slope Front system in the eastern Weddell Sea, Ocean, Ice, and Atmosphere: Interactions at the Antarctic Continental Margin, edited by: Jacobs, S. S. and Weiss, R. F., Antarctic Research Series, 75, Amer. Geophys. Union, 203-214, 1998.

Heywood, K. J., Naveira Garabato, A. C., Stevens, D. P., and Muench, R. D.: On the fate of the Antarctic Slope Front and the origin of the Weddell Front, J. Geophys. Res., 109, C06021, doi:10.1029/2003JC002053, 2004.

Jacobs, S. S.: The Antarctic Slope Front, Antarct. J. U.S., 21, 123 124, 1986.

Jacobs, S. S.: On the nature of the Antarctic Slope Front, Mar. Chem., 35, 9-24, 1991

Kerr, R., Heywood, K. J., Mata, M. M., and Garcia, C. A. E.: On the outflow of dense water from the Weddell and Ross Seas in OCCAM model, Ocean Sci., 8, 369-388, doi:10.5194/os-8-3692012, 2012.

Lacarra, M., Houssais, M.-N., Sultan, E., Rintoul, S., and Herbaut, C.: Summer hydrography on the shelf off Terre Adelie/George V Land based on the ALBION and CEAMARC observations during the IPY, Polar Science, 5, 88-103, doi:10.1016/j.polar.2011.04.008, 2011.

Martinson, D. G. and McKee, D. C.: Transport of warm Upper Circumpolar Deep Water onto the western Antarctic Peninsula continental shelf, Ocean Sci., 8, 433-442, doi:10.5194/os-8-4332012, 2012.

Mathiot, P., Goosse, H., Fichefet, T., Barnier, B., and Gallée, H.: Modelling the seasonal variability of the Antarctic Slope Current Ocean Sci., 7, 455-470, doi:10.5194/os-7-455-2011, 2011.

Muench, R. D. and Gordon, A. L.: Circulation and transport of water along the western Weddell Sea margin, J. Geophys. Res., 100, 18503-18515, 1995.

Palmer, M., Gomis, D., Flexas, M. D. M., Jorda, G., Jullion, L., Tsubouchi, T., and Naveira-Garabato, A. C.: Water mass pathways and transports over the South Scotia Ridge west of $50^{\circ} \mathrm{W}$, Deep-Sea Res. Pt. I, 59, 8-24, 2012.

Richardson, G., Wadley, M. R., Heywood, K. J., Stevens, D. P., and Banks, H. T.: Short-term climate response to a freshwater pulse in the Southern Ocean, Geophys. Res. Lett., 32, L03702, doi:10.1029/2004GL021586, 2005. 
Shimada, K., Aoki, S., Ohshima, K. I., and Rintoul, S. R.: Influence of Ross Sea Bottom Water changes on the warming and freshening of the Antarctic Bottom Water in the AustralianAntarctic Basin, Ocean Sci., 8, 419-432, doi:10.5194/os-8-4192012, 2012.

Thompson, A. F. and Heywood, K. J.: Frontal structure and transport in the northwestern Weddell Sea. Deep-Sea Res. Pt. I, 55, 1229-1251, 2008.

Wåhlin, A. K., Yuan, X., Björk, G., and Nohr, C.: Inflow of warm Circumpolar Deep Water in the central Amundsen shelf, J. Phys. Oceanogr., 40, doi:10.1175/2010JPO4431.1,1427-1434, 2010.
Wåhlin, A. K., Muench, R. D., Arneborg, L., Björk, G., Ha, H. K., Lee, S. H., and Alsén, H.: Some implications of Ekman layer dynamics for cross-shelf exchange in the Amundsen Sea, J. Physical Oceanography, 42, doi:10.1175/JPO-D-11-041.1, 2012.

Williams, G. D., Meijers, A. J. S., Poole, A., Mathiot, P., Tamura, T., and Klocker, A.: Late winter oceanography off the Sabrina and BANZARE coast (117-128 E), East Antarctica, Deep-Sea Res. Pt. II, 58, doi:10.1016/j.dsr2.2010.10.035, 2011.

Williams, G. D., Hindell, M., Houssais, M.-N., Tamura, T., and Field, I. C.: Upper ocean stratification and sea ice growth rates during the summer-fall transition, as revealed by Elephant seal foraging in the Adélie Depression, East Antarctica, Ocean Sci., 7, 185-202, doi:10.5194/os-7-185-2011, 2011. 